\title{
A.JO'ГE
}

African Journal of Teacher Education

ISSN 1916-7822. A Journal of Spread Corporation

Volume $9 \quad 2020 \quad$ Pages 1-20

\section{Higher Grading Standards and Academic Motivation: Perceptions of Students and Teachers in a Lagos (Nigeria) Private Secondary School}

\author{
Innocent Uche Anazia \\ School of Social Sciences, Education and Social Works (SSSESW) \\ Queens University Belfast, Belfast, UK
}

\begin{abstract}
.
This study used qualitative research method to investigate the views of students and teachers of a private secondary school in Lagos State, Nigeria on whether higher grading standards motivate students. The study was prompted by the decision of the management of the school to increase its grading standard. To guide the study, 10 students and 7 teachers participated in the study. Data were generated using interview technique which centred on two objectives or themes of the study. The first objective was targeted at both the students and teachers, while the second objective was targeted at teachers. Thematic analysis was used to analyze the perceptions of the students and teachers. The findings revealed that higher grading standards motivate students to study harder and that higher standards benefit both high-achievers and low-achievers. Considering that the study was the first attempt to investigate the issue as it concerns Nigeria, suggestions were made on future studies.
\end{abstract}

Keywords: Grading, grading standards, perception, academic motivation

\section{Introduction}

Ideally, a school should provide students the opportunity to learn in an academically stimulating environment. Effective learning takes place in a motivating atmosphere. Teachers and students will show greater commitment when they are motivated. Students are motivated by intrinsic and extrinsic factors. Intrinsic motivation has to do with self-motivation - the desire to learn for the sake of acquiring knowledge. In intrinsic motivation, students are keen on learning not just because they want to obtain a grade or get rewarded, but because they want to expand their knowledge (Blake, 2015). Extrinsic 
motivation on the other hand, refers to externally influenced factors. In this case, a student is motivated to learn or achieve not because of personal interest or the desire to acquire knowledge, but a desire to please others by meeting expectations set by parents, teachers, or factors like a desired grade or GPA (Blake, 2015). Blake (2015) further states that external motivation can also involve punishment and reward in that students might fear the punishment associated with obtaining a poor grade or the rewards that come with obtaining a high grade or GPA. Therefore, they see grading as a powerful academic communication tool.

Brookhart, Guskey, Bowers, et al (2016) define grading as "the symbols assigned to individual pieces of student work or composite measures of student performance on report cards". They traced the history of grading to the $19^{\text {th }}$ century when students' progress was communicated orally to parents by teachers at the homes of the students. A transition to written narrative reports followed by the turn of the $20^{\text {th }}$ century in high schools due to increasing diversity in student population and in subject areas taught (Guskey \& Bailey, 2001) as cited in Brookart et al (2016). Schneider and Hutt (2013) note that the use of grades as extrinsic motivation is influenced by the need to provide "a readily interpretable messages to future teachers, schools, and employers about the quality of the students" (p. 18). Gold, Reilly, Silberman, et al (1971) are of the view that students' learning experience in college education should be based on intrinsic motivation whereas, they claim, the use of grades by most colleges induce extrinsic motivation. Consequently, when students leave college the motivation for intellectual activity lapses because of the absence of grades.

Grading remains the major benchmark for evaluating students' performance in many educational institutions. Various grading systems are adopted such as the percentage grading, letter grading, pass/fail grading, among others. In Nigeria, letter grading system is widely used, especially at the primary and secondary school levels. In this grading system, students' overall performance (which comprises of exams and continuous assessments) are assigned letters from $\mathrm{A}-\mathrm{F}$ on percentage scores ranging from $0 \%-100 \%$. The grading policies for internal school exams at these lower levels of education are determined by state ministries of education in the case of public schools. While most private schools adopt government policies on grading, they can and often modify theirs as the case was at the school under focus in this study.

Grades serve myriad of purposes such as for promotion, placement, counseling, rewards, and motivation. However, there is limited knowledge of how well and in what ways these features are met 
(Lekholm, 2010). Harlin and Deakin (2002) posit that there have been controversies regarding the effect of grades on the learning, motivation and achievement of students for over 40 decades and that results from research are divergent (as cited in Lekholm, 2010). Despite these controversies, grading of students' academic performance remains a long tradition: part of the conventional school system (Krawczyk, 2017). Grades are used by educational institutions across all levels and around the world "as a fundamental sorting and signaling mechanism for students" (Faieza, 2018, p. 86). The method of assessment used by schools is based on their grading system. However, in a bid to suit the school, students, parents, and other stakeholders, grading systems have witnessed-changes over time. Some grading systems have grading standards which are determined by several factors such as the purpose of the assessments or tests, the school or examination body, and the performance of the test takers.

Since grading policies directly affect the grades obtained by students (Enwefa, 2015), the expectation is that schools would adopt policies and practices that are beneficial and help students to improve their academic and behavioural outcomes (Reeves, 2008). Grading standards can serve as incentives to some students and disincentives to others as higher standards may spur students who are more motivated to worker harder by increasing their efforts while at the same time, cause some students to become discouraged as the standard goes beyond their reach (Betts \& Grogger, 2003). Betts (1995) found that grading standards have more impact on stronger than on weak students as measured by their GPA (as cited in Betts, et al, 2003). Few empirical studies have been conducted on the effects of higher grading standards (Betts et al, 2003; Fallan \& Opstad, 2012; Figlio, et al 2003).

Nigeria's education system lays a lot of emphasis on grades. Students and teachers are rewarded based on grades; parents' decision to enroll their children and wards in a particular school is influenced by students' grades in external examinations such as the West African Senior School Certificate Examinations (WASSCE). Adepoju and Oluchukwu (2011) note that parents may refuse to send their children to schools that are not reputed for distinction and credit grades in English Language and Mathematics. Grade serves as a competitive tool among students as they strive to outdo each other in their class. Many students are very mindful of the rewards and punishments associated with grades. Considering that students respond to grades, when there are changes to the rules of assigning grades, it will result in changes in their behaviours and outcomes (Todd and Larry, 2005) because students derive personal satisfaction from achieving good grades (Musoleno and White, 2010). This study therefore seeks to investigate whether higher grading standards motivate students. 


\section{Study framework and rationale}

This study was prompted by the decision of the management of a private secondary school to change its grading standard. The table below shows the old and new grading standards.

Table 1: Old versus New Grading Standard

\begin{tabular}{|c|c|c|c|c|}
\hline \multicolumn{2}{|c|}{$\begin{array}{c}1 \\
\text { OLD GRADING STANDARD }\end{array}$} & \multicolumn{3}{|c|}{$\begin{array}{c}2 \\
\text { NEW GRADING STANDARD }\end{array}$} \\
\hline Score & Grade & Score & Grade & Remark \\
\hline \multirow{4}{*}{$75 \&$ above } & \multirow{4}{*}{ A } & $\begin{array}{l}91- \\
100\end{array}$ & $\mathrm{~A}++$ & EXCELLENT \\
\hline & & $\begin{array}{c}85- \\
90\end{array}$ & $\mathrm{~A}+$ & EXCELLENT \\
\hline & & $\begin{array}{c}80- \\
84\end{array}$ & A & EXCELLENT \\
\hline & & $\begin{array}{c}75- \\
79\end{array}$ & $\mathrm{~B}++$ & VERY GOOD \\
\hline \multirow{2}{*}{$65-74$} & \multirow{2}{*}{ B } & $\begin{array}{l}70- \\
74\end{array}$ & $\mathrm{~B}+$ & GOOD \\
\hline & & $\begin{array}{c}65- \\
69\end{array}$ & B & FAIRLY GOOD \\
\hline $60-64$ & $\mathrm{C}$ & $\begin{array}{c}60- \\
64\end{array}$ & $\mathrm{C}+$ & $\begin{array}{c}\text { ABOVE } \\
\text { AVERAGE }\end{array}$ \\
\hline \multirow{2}{*}{$50-59$} & \multirow{2}{*}{$\mathrm{D}$} & $\begin{array}{c}55- \\
59\end{array}$ & $\mathrm{C}$ & AVERAGE \\
\hline & & $\begin{array}{r}50- \\
54\end{array}$ & $\mathrm{D}$ & PASS \\
\hline $40-49$ & $E$ & \multirow{2}{*}{$0=49$} & \multirow{2}{*}{$\mathrm{F}$} & \multirow{2}{*}{ FAIL } \\
\hline $39 \&$ below & $\mathrm{F}$ & & & \\
\hline
\end{tabular}


The school principal, while addressing parents and members of staff during the parents-teachers forum on the issue, stated that the management of the school took the decision to change the grading standard in order to motivate the students to study harder and aim for "excellence". This was unanimously adopted by the parents after minor adjustments were made. The implementation of the new grading standard commenced in the 2018/2019 academic session.

From the table above, it can be observed that the grading standard was raised in Section 2 of the table. For instance, the "A" grade which was initially from $75 \%$ and above in the old grading standard was raised to $80 \%$ and above, with some distinctive features (the plus signs). The implication is that a student who initially maintained an "A" grade of $75 \%$ score would have to work harder to earn the same "A" grade in the new grading standard. Also, a weak student who had managed to maintain an "E" grade of $40-49 \%$ would have to strive to obtain $50-54 \%$ in the new grading standard if he or she is to escape from the "F" grade which means "Fail". Going by this, the study sought to ascertain if higher grading standards motivate students and by so doing, contributed to the limited studies on this topic.

Results from this study could influence the decisions of school heads, teachers and policy makers regarding grading policies. It could also provide information to researchers that are interested in issues about grades and grading policy to probe further and explore other pertinent areas.

\section{Objective of the study}

The aim of this study was to determine whether grading standards motivate students. Specifically, the study sought to determine whether:

1. higher grading standard motivates students

2. schools should set higher grading standards.

The objectives were developed from the rational of the study and a review of literature

\section{Literature review}

The literature on the effect of grading policies on students' motivation reveals divergent findings from few studies. Elikai and Schuhmann (2010) examined the impact of strict grading standard against a lenient grading standard on students' performance in a Cost Accounting course at the undergraduate level in a regional university through an experimental study. The lenient grading scale (or traditional 
grading scale) that they used was based on the following percentage points: $\mathrm{A}=90-100, \mathrm{~B}=80-89$, $\mathrm{C}=70-79, \mathrm{D}=60-69$, and $\mathrm{F}=<60$ percent. The strict grading scale was as follows: $\mathrm{A}=93-100$, $\mathrm{B}=85-92, \mathrm{C}=75-84, \mathrm{D}=65-74$, and $\mathrm{F}=<65$ percent. For the strict grading standard, the average mastery was "C" grade which coincidentally was the minimum passing requirement of the professional Accounting examinations. Their findings suggested that applying a strict grading standard would encourage Accounting students to put in more efforts in their studies and thus, acquire more knowledge and skills of the subject matter in readiness for professional examinations. Similarly, Johnson and Beck (1988) examined the relationship between strict and lenient grading scales and students' performance on tests administered in an undergraduate Educational Psychology class in Appalachian State University, North Carolina, USA, based on their performance in the Scholastic Aptitude Test (SAT). The subjects for the study were 91 undergraduate students who were enrolled in 11 sections of the Educational Psychology course over a period of three years. The strict grading scale was used for six sections, while the lenient scale was used for the remaining five sections. The strict scale was based on 8 percentage points such as $A=93-100, B=85-92$, etc. But 12 percentage points were used for the lenient scale such as $\mathrm{A}=89-100, \mathrm{~B}=77-88$. Their findings revealed that students with low SAT score performed better with the strict grading standard. They concluded therefore that students would perform better if strict grading is applied and further stated that lenient grading policy will negatively affect low ability students.

However, the studies of Elikai, et al (2010) and Beck (1988) in USA did not reveal the performance distribution standards of the students unlike the study conducted by Betts, et al (2003) which revealed mixed evidence of the effects of higher grading standards. Although the results of Betts, et al (2003) suggested that students respond positively to higher grading standards and that tests scores rise in schools with higher grading standards, they rise more for students near the top of the achievement distribution than for those near the bottom of the distribution.

The study conducted by Figlio and Lucas (2003) in Alachua County, Florida, USA, revealed that higher grading standards benefit students. Their findings proved that high-ability students benefit more from higher grading standard than low-performing students. But they observed that the effect of high grading standards is highest for high-ability students when classroom ability is relatively low.. They therefore concluded that high standards would motivate students to study harder and that parents who perceive that their children are struggling with their academic work would pay more attention to 
helping them with schoolwork than they may have done if they feel that their children are high achievers. Hussain, Rehman and Hussain (2014) also compared the performance of Pakistani engineering students on 5 letters lenient grading standard (A, B, C, D, F) and 7 letters (A, B+, B, C+, $\mathrm{C}, \mathrm{D}, \mathrm{F}$ ) strict grading standard. Their findings revealed that strict grading standard positively impacted significantly on the students' GPAs than the lenient grading standard. Interestingly, they reported that low performing students benefitted more from the strict grading standard than high-performing students.

The studies of Elikai, et al (2010), Johnson, et al (1988), Figlio, et al (2003) and Hussain et al (2014) were based on letter grading system. This grading system has the advantage of promoting extrinsic motivation and students' self-improvement (Melrose, 2017). However, Melrose (2017) notes that it gives room for unhealthy competition among students. Most students will prefer A and B grades which creates so much pressure to outperform one another and when they are able to obtain such grades, they see themselves as academically better than those that are unable to.

Researchers have also compared the effect of different grading systems on students' motivation and wellbeing. A study conducted by Robins, Fantone, Oh, et al (1995) compared a switch from honors, high/pass, pass and fail grading to just pass/fail by the university of Michigan Medical School, USA and revealed that students' performance and motivation did not decrease following the use of the new grading system and the students were satisfied with the new system. Similarly, the study of Bloodgood, Short, Jackson, et al (2009) on a change from letter grades to pass/fail (P/F) in a US Medical School showed no significant difference in performance but it improved students' wellbeing and satisfaction. In contrast, a study conducted by Gold, et al (1971) showed a decline in academic performance of college students who voluntarily opted to be assessed under pass/fail grading system. Gold et al opined that the reason could be the extrinsic motivation the students were already exposed to under the previous grading system and the pass/fail was probably to avoid rigorous study. The P/F grading is viewed as promoting the psychological wellbeing of the students in terms of reducing anxiety, burnout and competition (Austin, Allareddy and Petrie, 2018); and increases students' intrinsic learning motivation (Melrose, 2017). However, it reduces the opportunity of identifying excellent students and students' commitment to learning (Melrose, 2017). It seems that most college students prefer letter grades as identified by Leach, Queirolo, DeVoe, et al (2003). Leach et al are of the belief that "the 
choice between letter grade and pass/fail evaluation maybe based on students' motivations for achievement" (p. 496).

Chamberlin, Maï and I-Chant (2018) compared the impact of multi-level grading system and narrative evaluation on the academic motivation of students. Their findings revealed that grades did not increase the academic motivation of the students, but narrative evaluation enhanced their motivation. Similarly, Lipnevich and Smith (2008) found that descriptive feedback not accompanied by grades or praise had greater effect on the students. While narrative feedback could be useful in formative assessment, it may not be suitable for summative evaluation especially if not combined with any grading system. Most decisions on assessment reports (such as placement, promotion, rewards, etc.) are made based on summative evaluations. Using narrative feedbacks on summative evaluation could potentially limit such decisions. Also, narrative feedback is stressful and time-consuming for the teachers.

The study conducted by Aftab and Riaz (2016) investigated the impact of grade sensitivity on learning motivation and academic performance. Although not related to higher grading standard, the study is significant in explaining how much sensitive students are to grades and grading standards. They used a sample of 208 university students and their results showed that grade sensitivity has a positive influence on the learning motivation of students and their academic performance. This suggests that when students aim at obtaining certain grades or when they are aware of the implication of an increased grading standard, it will make them to study harder. But it may also lead to stress and burnout considering the effort that has to go into study.

In Nigeria, the use of traditional letter grading system has dominated assessment practices, especially at the primary and secondary levels. These grades clearly occupy the largest part of the students' report/result sheet (Enwefa, 2015). Enwefa's (2015) study in a Nigerian state raised the questions of whether teachers clearly understood grading policy of students' scores and whether students' works were graded appropriately. He discovered that teachers were subjective in awarding grades and included non-academic variables such as attendance in awarding grades, among other findings. These practices raise concern about the validity and reliability of grades awarded to the students. Räisänen, Tuononen, Postareff, et al (2016) note that grades serve as objective way of measuring achievement and therefore they "are trusted and relied on for important decisions and they play a major role in students' lives" (p. 181). Students' grades should be a true reflection of their 
academic abilities and aptitudes based on thorough instruction and adequate exposure to learning materials.

Contemporary studies on the effect of grading standards on student motivation and learning are very scanty as most of the studies were conducted in the 90s and earlier (Krawczyk, 2017). The few studies represented in the literature are mostly on schools in other countries, especially developed ones, and many of them focused at the university level. There is no such study in Nigeria. Much research, rather, has largely focused on continuous assessment (e.g. Awofala and Babajide, 2013; Onihunwa, Adigun, Irunokhai, et al, 2018; Faleye and Adefisoye, 2016; Osadebe and Uvietseivwi, 2018; Osadebe, 2015; Ale and Omirin, 2015; Alufohai and Akinlosotu, 2016). Furthermore, it is not also known whether the grading policies of Nigerian schools have any bearing on students' academic motivation or behaviours. Therefore, this study addresses this gap in the literature.

\section{Methodoly}

This qualitative research was conducted using case study approach. Zaidah (2007) states that using case study method enables the researcher to closely examine the data within a particular context and that such method selects a small geographical area or a very limited number of subjects. Qualitative method was adopted for two reasons: (1) the study framework and rationale centred on a particular school and, (2) most studies on the subject of grading standards are quantitative.

To guide the study, 10 students and 7 teachers were selected to elicit information regarding their perceptions on whether higher grading standards motivate students against the backdrop of the change of the school's grading policy. While the concept of saturation is considered as the principle behind sample size selection in qualitative study (Mason, 2010), Shari (2012) considers that from 5 to 50 participants are optimum. The participants were selected with the approval of the school. Effort was made to seek permission to from the school administration to waive anonymity to enhance the credibility of the study, but it was not granted by the school administration.

Data were generated using interview technique which centred on two objectives of the study. The first objective was targeted at the students and teachers, while the second objective was targeted at the teachers. The study considered the ability levels of the students (Johnson et al, 1988). In order to compare the views of the students on the basis of their academic performance with the new grading system in the first term examination (2018/2019 academic session), they were classified into two 
groups - High Achievers (HA) and Low Achievers (LA). 6 high-achievers were selected and 4 lowachievers were selected. Table 2 below shows the classification

Table 2: Classification of the students on the basis of academic performance

\begin{tabular}{|c|c|c|}
\hline Student & $\begin{array}{c}\text { Grade by overall } \\
\text { percentage (100\%) }\end{array}$ & Remarks (HA; LA) \\
\hline Student 1 & 94 & HA \\
\hline Student 2 & 97 & HA \\
\hline Student 3 & 94 & HA \\
\hline Student 4 & 94 & HA \\
\hline Student 5 & 92 & HA \\
\hline Student 6 & 92 & HA \\
\hline Student 7 & 55 & LA \\
\hline Student 8 & 59 & LA \\
\hline Student 9 & 53 & LA \\
\hline Student 10 & 58 & \\
\hline
\end{tabular}

HA: High-Achiever; LA: Low-Achiever

All the students that participated were chosen from senior school because they had a better understanding of the grading standards. Only teachers with considerable years of experience in the school were selected. This was to ensure that the teachers chosen were well familiar with the old and new grading standards. The table below shows the teachers chosen.

Table 3: Selected teachers on the basis of years of experience

\begin{tabular}{|c|c|}
\hline Teacher & $\begin{array}{c}\text { Years of } \\
\text { experience }\end{array}$ \\
\hline Teacher 1 & 7 \\
\hline Teacher 2 & 5 \\
\hline Teacher 3 & 4 \\
\hline Teacher 4 & 4 \\
\hline Teacher 5 & 4 \\
\hline Teacher 6 & 3 \\
\hline
\end{tabular}




\section{Analysis}

\begin{tabular}{|l|l|}
\hline Teacher 7 & 9 \\
\hline
\end{tabular}

Thematic analysis was used to analyze the perceptions of the students and teachers. Maguire and Delahunt (2017) stated that thematic analysis aims at identifying themes or patterns in the data that are important and these themes are used to address the research topic or issue. The objectives of the study formed the themes under which the perceptions of the respondents were analyzed.

\section{Results:}

\section{A. Students' perception}

\section{Higher grading standard as a motivator}

Majority of the students stated that higher grading standards motivate students to study harder. Further to this, the students expressed the views that grading standards benefit some students more than others. Most of them pointed that low-achieving students benefit more from a higher grading standard as it will motivate them to study harder

Student 1 noted:

Students who aim at particular grades or aim to maintain particular grades have to put in more effort to attain a higher score that can give them their desired grade

Student 2 also stated that:

A higher grading standard motivates students to work harder. . not only will the average and dull students work harder, the 'smart students' will have to study harder because they will see it as a way to distinguish themselves... smart students are so much exalted by their teachers and colleagues...

However, only student 4 did not consent to the fact that higher grading standards motivate students. She noted:

There are different types of students in school. Some are comfortable with any standard of grading while others are not. Well, grading standards motivate those students who have no problem accepting a challenge. But for those who find it difficult to challenge themselves may just give up on studying. 
Student 8 stated:

When the grading standard increases, it makes students study harder to reach their goals.

Student 8 stated as follows:

Some low achieving students would try harder to be better than the high-achieving students and the more they try, the more they get better at it.

Student 7 noted that:

High-achieving students are already used to a higher grading standard . . and such standard will make the low-achieving students to read more in order to get higher grades

Student 4 stated:

High-achieving students already feel they are the best in all the subjects and do not need to put in anymore effort. While they are thinking so, they may not know that a low-achieving student is working his way to the top...

\section{B: Teachers' perception}

\section{Higher grading standard as a motivator}

The teachers stated that higher grading standards motivate some students and discourage others. In addition, most of them noted that such standards motivate the brilliant ones and discourage the lowperforming students.

Teacher 4 stated:

Higher grading standards will work more for the more intelligent students. But for the struggling students, higher standards discourage them.

Teacher 5 noted that,

Higher standards challenge some students. But for the low-performing students, they could be discouraged.

Teacher 7 noted that: 
Higher Grading Standards and Academic Motivation: Perceptions of Students and Teachers in A Lagos (Nigeria) Private Secondary School

Higher grading standards will make the brilliant ones to work harder. But the low-achieving students will not be concerned because in private schools, students are promoted regardless of their performance

Teacher 5 noted that:

The standard is just set for those that are really intelligent. They are being helped to discover more excellent potentials about themselves.

Teacher 3 stated thus:

Higher standards benefit high-achieving students more. Low-performing students will have to struggle to meet up with average, but a high-achieving student has already set a standard for himself and cannot fall below.

Only Teacher 2 expressed a divergent view as follows:

While higher grading standards tell a high-achieving student to work more, it tells lowachieving student to also work more. It's a win-win situation for both sides.

\section{Setting higher grading standards by schools}

Majority of the teachers expressed the views that schools should set higher standards. Their views were based on standards set by public schools and external examination bodies in Nigeria such as the West African Examinations Council (WAEC).

Teacher 1 stated that:

It is good for schools to set higher standards because teachers may be lenient in say, awarding a 75\% "A" grade when for instance, an external exam has a higher standard. So students should be challenged.

Teacher 5 also stated that:

Higher grading standards will challenge senior students considering the standard set by external examinations.

Teacher 3 stated thus: 
Schools should begin to set higher standards to be in conformity with national examinations and present-day university admission requirements in the case of Nigeria. Students with more excellent grades have higher points and better chances of being admitted amongst the few that the university faculties can cater for.

Teacher 7 supported setting higher standards and faulted private schools where students hardly repeat classes when they fail to garner a certain overall percentage or grade unlike public schools where a student is asked to repeat if they do not score up to $50 \%$ in core subjects.

But teacher 4 stated that:

Schools should not set higher standards. It should be balanced. The low-achieving students should be considered.

\section{Discussion}

The first finding of the study as expressed by both the high-achieving and low-achieving students reveals that higher grading standards motivate students to work harder. This is in line with the findings of Elikai et, al (2010); Johnson, et al (1988); and Betts, et al (2003) which all revealed that setting higher or strict standards would motivate students to work harder. Also, Aftab, et al (2016) reported that when students are sensitive to grades, they would work harder. This means that when students are aware that the bar has been raised, they would be challenged to maintain or improve on their performance. It is also important to state that students now recognize grade as a competitive tool in their classes and, therefore, would strive to improve on their performance; as one of the students noted, when a student obtains good grades, they will have better prospects. Also, the finding from the students reveals that higher grading standards benefit the low-achieving students more than the high-achieving students which agrees with the result from the study of Rehman and Hussain (2014) where they reported that low performing students benefitted more from strict grading standard. But the views of the students are in contrast with the views of the teachers. Although some of the teachers stated that higher standards motivate students, they largely maintained that high-achieving students benefit more from higher grading standards than low-achieving ones. These divergent views could be as a result of their different experiences with grades. Teachers may have a different understanding of the students in terms of their sensitivity to changes in grading standards because teachers are the implementers of whatever standard that is set by the school or education/exam body. While teachers are the ones that 
teach and assign grades, students are the recipients. The views of the teachers are in line with the findings of Lucas, et al (2003) which revealed that high-ability students benefit more from higher grading standard than low-performing students. However, they (Lucas, et al ) also observed that the effect of high grading standards is highest for high-ability students when classroom ability is relatively low.

In the second finding, teachers expressed the view that schools should set higher grading standards. As Lucas, et al (2003) reported in their findings, setting higher grading standards benefit students. The views of the teachers are widely based on comparison with the standards set by external examination bodies in Nigeria such as the West African Examinations Council (WAEC) and the National Examinations Council (NECO). One of the teachers noted that higher standard is important considering that some teachers may be lenient in internal examinations whereas external examinations maintain strict grading policies. For instance, in the WAEC grading system, the A grade which is classified as "A1" falls within $80 \%-100 \%$. As observed by Johnson et al (1988), a lenient grading policy will have negative effect on the students (who for example in their WAEC exam would be assessed based on their grading standard that is higher).

Also, one of the teachers compared the standard set by private schools and that of public schools and stated that private schools should set standards that are comparable to public schools. The standards set by public schools are higher than in most private schools. This is because private schools try to justify the huge payments made by parents and therefore, students no longer repeat classes in most private schools in Nigeria when they do not perform well or obtain the minimum grade level that will move them to the next class. These private sector schools use this method as a means of overcoming the competitive market for private education.

\section{Conclusion}

This study attempted to obtain the views of students and teachers of a private secondary school in Lagos, Nigeria with regards to grading standards. This study was prompted by the decision of the management of the school to raise the grading standards as a way of motivating the students. A thorough review of the literature revealed that researchers (such as Krawczyk, 2017 and Betts, et al 2003) have lamented over the limited studies on the subject of higher grading standards and academic 
motivation. It was also discovered that there are no studies on the issue investigated in the case of Nigeria.

From the findings, the study concludes that setting higher grading standards would motivate students to worker harder in order to maintain or improve their academic performance. Students will do better when they realize that they need to work towards a higher standard. They will pay more attention in class, copy their notes, complete all assignments and other tasks and study more towards their examination.

This study also concludes, based on the views of the students and the teachers, that higher grading standards benefit both the high-achieving students and the low-performing ones. This is because higher standards are meant to ensure that the high-achieving students do not rest on their oars and also ensure that low-performing ones are encouraged to put in more effort. It is important that the low-performing ones are given all the necessary support that they need to succeed. For instance, schools can organize extra-mural classes for them so that they can catch up with the more brilliant students. Going by the effect of grades on students' academic motivation and their internal and external uses, it is important that teachers adhere to ethical practices in assessing students as this will ensure the validity and reliability of grades awarded to students.

\section{Suggestions for further research}

Considering that this study was the first attempt in Nigeria aimed at discovering whether higher grading standard motivate students, the researcher therefore suggests the following:

1. More studies should be conducted using both quantitative and qualitative methods

2. Larger sample size should be used for subsequent studies which should involve junior students

3. A comparison should be made between private schools and public schools on the same topic investigated in this study to obtain wider views and information. 


\section{Reference}

Adepoju, T. L. \& Oluchkwu, E. E. (2011) A study of secondary school students' academic performance at the senior school certificate examinations and implications for educational planning and policy in Nigeria. International Multidisciplinary Journal Vol. 5(6). pp. 314-333. DOI: http://dx.doi.org/10.4314/afrrev.v5i6.26

Aftab, S. \& Riaz, S. (2016). Impact of Grade Sensitivity on Learning Motivation and Academic Performance. International Journal of Educational and Pedagogical Sciences, 10(7).

Ale, V. M. and Omirin, M. S. (2015). Teachers' perception and implementation of continuous assessment practices in secondary schools in Ekiti State, Nigeria. Journal of Education and Practice, 6(29). Available at https://files.eric.ed.gov/fulltext/EJ1081279.pdf

Alufohai, P. J. and Akinlosotu, T. N. (2016). Knowledge and attitude of secondary school teachers towards continuous assessment practices in Esan Central senatorial district of Edo state. Journal of Education and Practice, 7(10). Available at https://files.eric.ed.gov/fulltext/EJ1099655.pdf

Austin, K., Allareddy, V \& Petrie, C. S. (2018). Should pass/fail grading be used instead of traditional letter grade in dental education? Journal of Dental Education, 82(12). doi: 10.21815/JDE.018.131

Awofala, A. O. A. and Babajide, V. F. T. (2013). Continuous assessment practices among Nigerian preservice STM teachers. Journal of Education and Practice, 4(13). Available at https://pdfs.semanticscholar.org/9577/2f63e51def79b4e41fc3474ff23c90eeff3d.pdf

Betts, J. R. \& Grogger, J. (2003) The Impact of Grading Standards on Student Achievement, an EntryLevel Earnings. Economics of Education Review 22 (2003) pp 343-352. Retrieved from http://citeseerx.ist.psu.edu/viewdoc/download?doi=10.1.1.529.7261\&rep=rep1\&type=pdf

Blake, C. (2015). Cultivating Motivation: How to Help Students Love Learning. Retrieved from https://education.cu-portland.edu/blog/classroom-resources/cultivating-student-motivation/

Bloodgood, R. A., Short, J. G., Jackson, J. M. \& Martindale, J. R. (2009). A change to pass/fail grading in the first two years at one medical school results in improved psychological wellbeing. Acad Med., 84(5), pp. 655-62. doi: 10.1097/ACM.0b013e31819f6d78.

Brookhart, S. M., Guskey, T. R., Bowers, A. J., McMillan, J. H., Smith, J. K.; Smith, L. F., Stevens, M. T. \& Welsh, M. E. (2016). A Century of Grading Research: Meaning and Value in the Most Common Educational Measure. Educational, School, and Counseling Psychology Faculty Publications, 2. Available at https://uknowledge.uky.edu/edp_facpub/2

Chamberlin, K., Yasué, M. \& I-Chant, A. C. (2018). The impact of grades on student motivation. Active Learning in Higher Education, 1 -16. DOI: 10.1177/1469787418819728 
Elikai, F. \& Schuhmann, P. W. (2010). An Examination of the Impact of Grading Policies on Students' Achievement. Issues in Accounting Education, American Accounting Association, 25(4), pp. 677-693. DOI: 10.2308/iace.2010.25.4.677.

Emil S. (2012) The Role of Grades in Motivating Students to Learn. International Conference on Education and Educational Psychology (ICEEPSY 2012) https://doi.org/10.1016/j.sbspro.2012.12.156

Enwefa, C. (2015). Grading practice as valid measures of academic achievement of secondary schools students for national development. Journal of education and practice, 6(26)

Available at https://files.eric.ed.gov/fulltext/EJ1077389.pdf

Faieza, C. (2018). Grade Inflation: Causes, Consequences and Cure. Journal of Education and Learning, 7(6). https://doi.org/10.5539/jel.v7n6p86

Fallan, L., \& Opstad, L. (2012). Attitudes towards study effort response to higher grading standards: Do gender and personality distinctions matter? Journal of education and learning, 1(2). http://dx.doi.org/10.5539/jel.v1n2p179

Faleye, B. A. and Adefisoye, B. T. (2016). Continuous assessment practices of secondary school teachers in Osun State, Nigeria. Journal of Psychology and Behavioural Science, 4(1), pp. 4455. https://doi.org/10.15640/jpbs.v4n1a5

Figlio, D. N., \& Lucas, M. E. (2003). Do High Grading Standards Affect Student Performance? University of Florida and National Bureau of Economic Research School Board of Alachua County, $\quad$ Florida. $\quad$ Retrieved from http://citeseerx.ist.psu.edu/viewdoc/download?doi=10.1.1.691.960\&rep=rep1\&type=pdf

Gold, R. M., Reily, A., Silberman, R. \& Lehr, R. (1971). Academic achievement declines under pasfail grading. The Journal of Experimental Education, 39(3).

Hussain, A., Rehman, S. U. and Hussain, I. (2014). Effect of Grading Policy on Students' CGPA-A Case Study of an Engineering College. International Journal of an Engineering Research and Development, 10(7), pp.01-09

Johnson, B. G., \& Beck, H. P. (1988). Strict and lenient grading scales: How do they affect the performance of college students with high and low SAT Scores? Teaching of Psychology, pp. 153: 127-131

Krawczyk, R. M. (2017). Effects of Grading on Student Learning and Alternative Assessment Strategies. Retrieved from: https://sophia.stkate.edu/maed/223

Leach, C. W., Queirolo, S. S., DeVoe, S. \& Chemers, M. (2003). Choosing letter grade evaluations: The interaction of students achievement goals and self-efficacy. Contemporary Educational Psychology, 28 (2003), pp. 495-509 
Lekholm, A. K. (2010). Effects of Grades on Student Motivation and Learning in Compulsory School. Conference paper. Retrieved from https://www.eera-ecer.de/ecerprogrammes/conference/3/contribution/4245/

Lipnevich, A. A. \& Smith, J. K. (2008). Response to Assessment Feedback: The Effects of Grades, Praise, and Source of Information. Available at https://www.ets.org/Media/Research/pdf/RR08-30.pdf

Maguire M. \& Delahunt, B. (2017). Doing a Thematic Analysis: A Practical, Step-by-Step Guide for Learning and Teaching Scholars. The All Ireland Journal of Teaching and Learning in Higher Education, 9(3). Retrieved from http://ojs.aishe.org/index.php/aishe-j/article/view/335

Mason, M. (2010). Sample size and saturation in PHD studies using qualitative interviews. Forum: Qualitative Social Research, 11(3)

Melrose, S. (2017). Pass/Fail and Discretionary Grading: A Snapshot of Their Influences on Learning. Open Journal of Nursing, 7, pp. 185-192

Musoleno, R. R, \& White, G. P. (2010). Influences of high-stakes testing on middle school mission and practice. Online research in middle level education, 34(3)

Onihunwa, J., Adigun, O., Irunokhai, E., Sada, Y., Jeje, A. Adeyemi, O. \& Adesina, O. (2018). Roles of continuous assessment scores in determining the academic performance of computer science students in Federal college of wildlife management. American Journal of Engineering Research, 7(5), pp. 07-20.

Osadebe, P. U. (2015). Evaluation of continuous assessment practice of university lecturers. International Journal of Evaluation and Research in Education, 4(4), pp 215 - 220. Available at https://files.eric.ed.gov/fulltext/EJ1091717.pdf

Osadebe, P. U. \& Uvietesivwi, O. A. (2018). Assessment of teachers' implementation of continuous assessment in senior secondary schools in Delta Central Senatorial district. Advances in Social Sciences Research Journal, 5(7). DoI:10.14738/assrj.57.4466.

Räisänen, M., Tuononen, T., Postareff, L., Hailikari, T. \& Virtanen, V. (2016). Students' and Teacher's Experiences of the Validity and Reliability of Assessment in a Bioscience Course. Higher Education Studies, 6(4). Available at https://files.eric.ed.gov/fulltext/EJ1121225.pdf

Reeves, D. (2008). Effective grading practices. Educational Leadership, 65 (5), pp. 85-87

Robbins, L., Fantone, J. Oh, M., Alexander, G., Shlafer, M. \& Davis, W. (1995). The effect of passfail grading and weekly quizzes on first-year students' performances and satisfaction. Academic Medicine, 70(4), pp. 27-9

Schneider, J. \& Hurt, E. (2013). Making the grade: a history of the A-F marking scheme. Journal of Curriculum Studies, 46(2). DOI: 10.1080/00220272.2013.790480

Shari, L. D. (2012) 'Sample size policy for qualitative studies using in-depth interviews'. Arch Sex Behav., 41, pp1319-1320. DOI 10.1007/s10508-012-0016-6 
Todd L. C., \& Larry, V. E. (2005). Does Rank-Order Grading Improve Student Performance? Evidence from a Classroom Experiment. International Review of Economics Education, 4(1), pp. 9-19. DOI: $\underline{10.1016 / \mathrm{S} 1477-3880(15) 30140-7}$

Ugboh, L. A. (2012). Problems of implementing continuous assessments in secondary schools in Obowo local government area of Imo state, Nigeria. Journal of Technology and Education in Nigeria, 17(2). Available at https://www.ajol.info/index.php/joten/article/view/119392

Zaidah, Z. (2007). Case study as a research method. Retrieved from http://psyking.net/htmlobj$\underline{3837 / \text { case study as a research method.pdf }}$ 